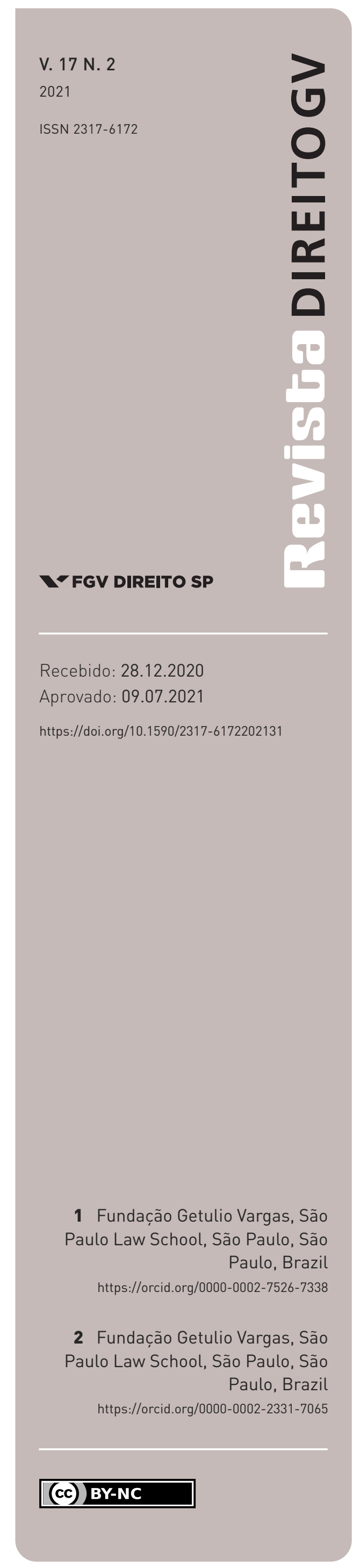

\section{International Cooperation and Negotiated Settlements for Transnational Bribery: A Study of the Odebrecht Case}

\author{
COOPERAÇÃO INTERNACIONAL E ACORDOS DE LENIÊNCIA EM CASOS DE CORRUPÇÃO \\ TRANSNACIONAL: UM ESTUDO DO CASO ODEBRECHT
}

Raquel de Mattos Pimenta ${ }^{1}$ and OtavioVenturini ${ }^{2}$

\begin{abstract}
Transnational regulation of bribery involves several increasingly complex forms of cooperation among enforcement authorities. International investigative cooperation allows a foreign authority to assist another on criminal and/or civil investigations, through requests of mutual legal assistance, rogatory letters, as well as joint investigative teams. Sanction-based cooperation helps different authorities to transfer or extradite persons and recover proceeds of corruption to the victims. More recently, there has been a rise in cooperation in negotiated settlements with the accused. Settlement cooperation may entail joint resolutions or the coordination of settlement clauses. This paper focuses on how these three modes of cooperation intersect in cases with successive negotiated settlements. We use the Odebrecht case settlements to unpack the relation between investigative, sanction-based, and settlement cooperation in three case studies: the joint resolutions between the company and Brazil, Switzerland, and the United States, as well as two local agreements with the Dominican Republic and with Peru. We evidence how these modes of cooperation can reinforce or undermine one another. Beyond illustrating different cooperation dynamics, we also explore the role of sequencing. The existence of a previous joint resolution affects the developments of the subsequent agreements, but in different ways from those previously mapped by the literature.
\end{abstract}

\section{Keywords}

Transnational bribery; negotiated settlements; international cooperation; coordination; Odebrecht.

\section{Resumo}

A regulação transnacional anticorrupção promove formas de cooperação cada vez mais complexas entre autoridades. A cooperação internacional em investigações permite que as autoridades auxiliem umas às outras em suas investigações criminais e/ou civis, por meio de solicitações de assistência jurídica mútua, cartas rogatórias e até mesmo equipes de investigação conjuntas. A cooperação baseada em sanções possibilita a transferência ou a extradição de pessoas, bem como a recuperação de ativos para as vítimas da corrupção. Mais recentemente, há aumento da cooperação entre autoridades por meio de acordos negociados com os acusados. Tal cooperação pode implicar resoluções conjuntas ou a coordenação de cláusulas específicas de acordos celebrados. 0 artigo analisa como esses três modos de cooperação se relacionam quando há acordos sucessivos negociados em diferentes jurisdições. Utilizamos o caso Odebrecht para desvendar a relação entre cooperação em investigação, cooperação baseada em sanções e cooperação em acordos de colaboração em três estudos de caso: as resoluções conjuntas entre Odebrecht e Brasil, Suíça e Estados Unidos, e dois acordos locais firmados com a República Dominicana e com o Peru. Mostramos como esses modos de cooperação podem reforçar ou enfraquecer uns aos outros. Além de ilustrar diferentes dinâmicas de 
INTERNATIONAL COOPERATION AND NEGOTIATED SETTLEMENTS FOR TRANSNATIONAL BRIBERY :

cooperação, também exploramos o papel da sequência entre os acordos em diferentes jurisdições. A existência de uma resolução conjunta anterior afeta os desdobramentos dos acordos subsequentes, mas de formas distintas daquelas previamente mapeadas pela literatura.

Palavras-chave

Corrupção transnacional; acordos de leniência; cooperação internacional; coordenação; Odebrecht.

\section{INTRODUCTION $^{1}$}

International regulations on transnational bribery required decades to be undertaken (ABOTT and SNIDAL, 2002; DAVIS, 2010). ${ }^{2}$ Even the pioneering U.S. legislation, the 1977 Foreign Corrupt Practices Act (FCPA) remained largely dormant until the 2000s when cases and fines began to grow vertiginously (BREWSTER and BUELL, 2017). Other countries slowly began to modify their domestic legal framework and, in the last decade, started to sanction transnational bribery (BREWSTER, 2017; ROSE, 2015). ${ }^{3}$

This situation results in a complex institutional environment with different treaties interacting with domestic legal frameworks, interpreted by a fragmented set of actors (law enforcement

1 Editors' note: This article was evaluated by two anonymous reviewers, by guest editors Kevin Davis, Mariana Mota Prado and Marta Rodriguez de Assis Machado and by Catarina Helena Cortada Barbieri, the editor-in-chief of Revista Direito GV.

2 The 1996 Inter-American Convention against Corruption (IACAC) was ratified by all active OAS members. The Organization for Economic Cooperation and Development's 1999 Convention on Combating Bribery of Foreign Public Officials in International Business Transactions (OECD Convention), which focused exclusively on the transnational dimension of bribery, contemplates 44 signatories. The UN's 2003 Convention against Corruption (UNCAC) is the most encompassing anticorruption treaty, both in its provisions and in signatories, with over 140 State signatories.

3 TI's latest report (2020) on the OECD Convention considers that there are currently 13 countries with active or moderate enforcement efforts on transnational bribery. The report recognizes that only four countries actively enforce against foreign bribery, which represents $16.5 \%$ of global exports. Even among enforcers (active or moderate), the importance and scope of action of the U.S. authorities remain unmatched. According to the AS/COA's Anti-Corruption Working Group's CCC Index (2020), at least 7 countries in Latin America have a moderate to high capacity to combat corruption domestically: Uruguay, Chile, Costa Rica, Brazil, Peru, Argentina, and Colombia. They may face diverse challenges to enforce provisions, however, the number illustrates the existence of enforcement capacity in the region. 
authorities, companies and international organizations, etc. What types of conduct to sanction, who to hold liable, which sanctions to impose and how to allocate responsabilities are policy choices scattered through these different frameworks (DAVIS, 2019). Plus, different actors may reasonably disagree on how to balance claims of condemnation, reparation, prevention, or how to evaluate each of these objectives (DAVIS, 2019).

The emergence of new enforcers, the existence of reasonable disagreement on how to pursue cases, the absence of hierarchy and the fact that transnational bribery cases can affect multiple countries simultaneously are hallmarks of this regime. Yet, there is a growing emergence of cooperation and common understandings among different actors. Anticorruption treaties, mutual legal assistance treaties, ${ }^{4}$ international fora and networks ${ }^{\mathbf{5}}$ and even unilateral actions by some actors create conditions for cooperation to emerge.

In order to understand international cooperation in the regulation of transnational bribery, it is crucial to learn how the intersection of institutions and rules which commonly govern the field shapes the decision-making of States and non-State actors. ${ }^{6}$ This is consistent with Alter and Raustiala (2018) who argue that twenty-first-century international cooperation in any given area is best understood by looking at the entire regime complex, which is the "array of partially overlapping and non-hierarchical institutions governing a particular issue area” (RAUSTIALA and VICTOR, 2004). This paper contributes to this effort by highlighting and exploring how different modes of cooperation intersect in transnational bribery cases that use a particular technique: negotiated settlements. ${ }^{\mathbf{7}}$

International cooperation in transnational bribery cases involves authorities from different countries assisting each other in their criminal or civil cases. It can occur during investigations, when foreign authorities can help to collect evidence, execute searches and seizures, locate assets and collect statements. International cooperation can also occur in the sanctioning phase as foreign authorities help to extradite or transfer persons or return the proceeds of

$4 \quad$ The legal frameworks for providing and obtaining mutual legal assistance can range from rogatory letters to bilateral treaties and multi-lateral treaties.

$5 \quad$ For instance, the OECD Working Group on Bribery supports biannual meetings for law enforcement officials (The Global Network of Law Enforcement Practitioners Against Transnational Bribery) to encourage peer learning, the exchange of experiences and cross-border cooperation. See OECD (2019b).

6 Davis, Jorge and Machado define transnational anticorruption law as "a rather disorderly series of interactions between local, foreign, and supranational legal institutions, prompted by specific actions or events, with each set of interactions both being shaped by and shaping the institutions involved" (2016, p. 667).

7 We use this term interchangeably with non-trial resolutions or non-trial agreements. They may receive specific names in each country. When we are referring to the specific instrument in the countries, it is possible to use the name attributed by the country, as leniency agreement (Brazil), effective collaboration (Peru), non-prosecution agreements or deferred prosecution agreements (USA). 
corruption to victims. Many of these forms of cooperation are encouraged and regulated by international treaties. Investigative cooperation provisions can be found in anticorruption conventions $^{8}$ and mutual legal assistance treaties (MLATs). Sanction-based cooperation can also be part of conventions or MLATs, or in dedicated instruments, such as extradition agreements. Investigative cooperation and sanction-based cooperation can be achieved through formal instruments such as joint investigative teams, requests for mutual legal assistance, extradition requests or rogatory letters.

Investigative cooperation can also occur through informal exchanges among authorities, including non-coercive investigative measures or spontaneous disclosure (OECD, 2017, p. 140; DANDURAND, COLOMBO and PASSAS, 2007). Different jurisdictions may have burdensome procedural and evidentiary laws or other legal barriers (ARLEN and BUELL, 2020). ${ }^{9}$ Delays in cooperation may cause the cases to cease or provide the time and opportunity for evidence to disappear or assets' freezing to lapse (OECD, 2012). In sensitive cases, some law enforcers consider that formal proceedings may tip off central authorities that are not involved in the investigation, risking undesirable leaks. The limits for such informal exchange are disputable. Informal investigative cooperation may lead to inadmissible evidences in domestic courts, violation of the defendants' rights, as well as increased risks of annulments and setbacks. According to the OECD, 13\% of foreign bribery cases are evidenced by law enforcement authorities through formal and informal mutual legal assistance exchanges between countries (OECD Foreign Bribery Report, 2014).

A third form of cooperation between authorities, called settlement cooperation, is on the rise. Currently, most transnational bribery cases are resolved using negotiated settlements, especially with corporations. ${ }^{10}$ A negotiated settlement consists of an agreement between enforcement authorities and the accused, in which the latter receive reduced sanctions in exchange for further evidence, cooperation with authorities, reparation, and/or adoption of compliance

8 The OECD, for instance, defines mutual legal assistance as a process in which a Party executes in its territory an official act to gather evidence against a legal person within the scope of the Convention concerning criminal offences and other non-criminal proceedings, requested by another State Party. IACAC also provides measures of mutual assistance to be adopted by State Parties in order to obtain evidence and means of preventing, detecting, investigating, as well as punishing acts of corruption. UNCAC requires member States to afford the widest measure of mutual legal assistance in investigations, prosecutions, and judicial proceedings in relation to the offenses covered by the convention.

9 For instance, mutual legal assistance treaties must be respected for dual criminality. A request can only be executed if the offense also exists in the domestic legislation of the receiving State (OECD, 2012).

10 Currently, the U.S. solves 96\% of its Foreign Corrupt Practices Act investigations through some type of settlement. Germany and the United Kingdom solve 79\% of their foreign bribery cases without a full trial (OECD, 2019). The International Bar Association estimates that 57 countries allow some form of settlement for foreign bribery offenses (MAKINWA and SØREIDE, 2018, p. 15). 
measures (OECD, 2019). Depending on the country, negotiated settlements may be governed by different rules and procedures and may apply to corporations as well as individuals. Makinwa and Søreide (2018, p. 16-17) consider that settlements may be a full alternative to criminal trials or administrative liability (de jure settlement model). In this case, settlements are likely to merge enforcement steps: investigation and sanctioning are simultaneously part of the negotiations. ${ }^{11}$ Settlements can also take the form of pleas or bargains that mitigate sanctions but are not a substitute for traditional proceedings (de facto settlement model). In this second case, settlements are an alternative to adjudication, following investigation and preceding sanctioning steps. They may include further cooperation from the accused or simply terminate the case.

Both de jure and de facto negotiated settlements may offer benefits for investigation, sanctioning, and/or prevention. They can increase detection by providing incentives for the accused to come forward voluntarily, identify other wrongdoers or offer further evidence. In terms of sanctions, negotiated settlements can avoid lengthy and uncertain trials, while providing for financial penalties, reparations, and recovery of proceeds of corruption that may otherwise remain hidden (PIETH, 2020; ODUOR et al., 2014). The resulting savings in resources allocated to investigation and sanctioning can allow more resources to be deployed in other investigations. Settlements with corporations can also encourage corporate policing (ARLEN, 2020) and a culture of compliance (ODED, 2020).

On the other hand, settlements can jeopardise the operation of justice systems. Settlements question the transparency, predictability and accountability of negotiating parties. In de jure settlements, negotiations may be opaque, especially if they are not submitted to judicial oversight or if the review process is limited to formal aspects. In de facto settlements, expediting adjudication may be a priority, as it focus less on prevention (MAKINWA and SØREIDE, 2018). Most of all, negotiated settlements mitigate sanctioning of the accused. Whether these techniques can deter and prevent wrongdoings is a open debate (IVORY and SØREIDE, 2020).

The transnational regulation of negotiated settlements is almost absent, ${ }^{12}$ only implicitly endorsed by international organizations (IVORY and SØREIDE, 2020). The absence of

11 Makinwa and Søreide (2018, p. 26) point out that settlements pose an authority with several enforcement functions: "A prosecuting office first handles the investigation of a case, secondly serves as a regulator who evaluates an alleged offender's self-reporting, cooperation and compliance system, and thirdly, it is the 'judge' who offers a penalty that ends the case." Judicial oversight only mitigates these problems partially (p. 26). Pimenta (2020, p. 29) argues that corporate settlements in the Brazilian context not only concentrate functions in specific actors, but also merges the traditional legal accountability sequence of monitoring, investigating and sanctions, which are done simultaneously at the negotiation table.

12 The UNCAC has general provisions to protect whistleblowers, however it is not completely regulated and neither addresses core concerns of negotiated settlements. The article 37(5) anticipates some form of coordination among authorities when the defendant which is in one State can provide useful information 
guidelines impacts how a single jurisdiction balances the potential and avoids the pitfalls of a negotiated settlement. The gap on transnational regulation also complicates any interaction among countries in transnational cases. Regarding multijurisdictional enforcement, settlements with companies and individuals expand their exposure to foreign authorities. Instead of reduced sanctions, companies and individuals that decide to settle may face even more investigations and sanctions.

Multijurisdictional enforcement can create chilling effects on self-reporting to any single jurisdiction, as individuals and companies may be more reluctant to share information with one country that may be used against them elsewhere (ODED, 2020; HOLTMEIER, 2015). Sometimes several countries negotiate successive agreements with the accused arising from the same or related sets of facts. Some authors accept that several countries may have or claim legitimacy to negotiate settlements but consider these "carbon copy agreements" deleterious as they may lead to over-deterrence, double jeopardy, as well as a waste of public resources (BOUTROS and FUNK, 2012; ODED, 2020).

The risks of overlapping enforcement actions have led some countries to cooperate during the negotiation of these agreements. Settlement cooperation has become notorious in the last decade through high-profile cases such as Siemens (UNITED STATES OF AMERICA, 2018) or Airbus (UNITED STATES OF AMERICA, 2020). They may include joint resolutions or specific understandings between authorities on some of the settlements' provisions, for instance, by recognizing and crediting fines applied elsewhere (ODED, 2020).

Established forms of investigative and sanction-based cooperation have been discussed in literature. In recent years, the rise of settlement cooperation has also received its due to attention. Settlement cooperation does not fit previous modes of international cooperation. When they are considered as full alternative to trials, as in de jure models, authorities can simultaneously negotiate between themselves and the accused over the evidence to be submitted and the sanction and distribution of fines between authorities. When they are not considered as full alternative to trials, the settlements can add evidence and facts to the cooperating authorities' investigations. ${ }^{13}$ Previous studies do not focus on systematizing how these modes of

to another State: "1. Each State Party shall take appropriate measures to encourage persons who participate or who have participated in the commission of an offence established in accordance with this Convention to supply information useful to competent authorities for investigative and evidentiary purposes and to provide factual, specific help to competent authorities that may contribute to depriving offenders of the proceeds of crime and to recovering such proceeds".

13 Depending on the applicable domestic law, some de facto settlements may simply terminate the cases usually conducted under a court's approval, without requiring further cooperation from the accused. In this case, settlement cooperation would be beneficial as it avoids overlap, and possibly sharing penalties. However, it would not interfere with investigative cooperation as the accused would not be required to bring forth any 
cooperation affect each other, especially in an environment with an increased likelihood of enforcement by multiple agencies using negotiated settlements.

The coexistence of these three different modes of cooperation - investigative, sanctionbased and settlement - shapes the decision-making of authorities and companies. More importantly, the way they affect each other is neither unidirectional nor predetermined, enabling further analysis. In this paper, we show how these different modes of cooperation can reinforce each other in some cases and undermine one another.

These modes of cooperation can be complementary. For instance, intense investigative cooperation between authorities can provide multiple interactions that allow them to adjust strategies and establish favourable conditions to settlement cooperation (DAVIS, 2016). The opposite may also be true. Cooperating on settlements may provide evidence and penalties which can expedite and help to overcome the hurdles of investigative cooperation and sanction-based cooperation.

These modes of cooperation can also undermine each other. Settlement cooperation involves not only the interaction of authorities from different countries but also negotiations with a private party. Individuals and companies rely on a particular set of incentives to come forward (ARLEN, 2020). If the signatory authority shares the evidence obtained through the agreement with other countries by using investigative cooperation mechanisms, it results in the increase of the exposure of the accused elsewhere. This is considered to be highly sensitive as in several of these negotiated agreements the accused must admit guilt and waive their right to prevent self-incrimination (LOW and PRELOGAR, 2020; ODED, 2020).

In addition, settlement cooperation may not include all affected countries on a transnational case which may hamper sanction-based cooperation, especially in asset recovery. More authorities negotiating a joint resolution may result in a delay or even bring substantive disagreements on financial and non-financial sanctions, distribution of proceeds or other issues (BOUTROS and FUNK, 2012). Thus, most settlement cooperation is limited to a few authorities. The division of recoveries with other countries through sanction-based cooperation may entail new lenghty negotiations after reaching a joint resolution. If new fines and penalties are added as a result, they can further strain the resources of the accused.

Throughout this paper, we explored the intersection between the three modes of cooperation in the context of successive negotiated settlements. To do so, we explore the Odebrecht ${ }^{14}$ corruption case, the scandal that swept Latin America. The first major settlement reached

information to the authorities. It is important to highlight that the settlement regimes of all the countries analyzed in this paper are classified as de jure models by Makinwa and Søreide (2018), except for the regime in the Dominican Republic, which was not classified. We believe it would merit the same label. In this scenario, de facto settlements were not analyzed without further cooperation from the accused.

14 At the end of 2020, following a broad corporate restructuring, Odebrecht announced it would be renamed "Novonor" (HIRATA, 2020). 
by the company involved cooperation between Brazil, the U.S. and Switzerland in 2016. The descriptions of the Odebrecht case usually focus on this arrangement (DAVIS, 2019; ODED 2020). However, our analysis move beyond these countries.

This first set of resolutions triggered investigations and settlements with agencies across the region. Considering the date of writing, Odebrecht has reached other non-trial resolutions with the Dominican Republic, Panama, Ecuador, Guatemala, and Peru. ${ }^{15}$ The paper focuses on the initial resolutions and the subsequent cases of the Dominican Republic and Peru. These cases have been selected for pragmatic reasons - as they have public information available, especially on the particular terms of the settlements - and because they offer a stark contrast in terms of international cooperation, which provide a useful variation of the interactions we aim to explore. (SEAWRIGHT and GERRING, 2008). The Brazilian, Swiss, and U.S. joint resolutions are a praised example of settlement cooperation. The Dominican Republic was not part of the joint resolutions, and neither relied on the settlement cooperation nor on investigative cooperation to settle with the company. Peru was also not part of the joint resolutions but it developed continuous investigative cooperation with the Brazilian authorities that, we argue, paved the way for the local agreement.

These case studies draw on a broad range of sources. We canvassed the U.S. Department of Justice's filings and official statements. Official documents were analyzed, particularly the non-trial agreements (or their public versions) in the selected countries. We also used the database of international cooperation requests (mainly evidentiary requests) created by Transparency International in partnership with Jota news portal (JOTA and TRANSPARÊNCIA INTERNACIONAL BRASIL, 2019). As it is centered on requests sent or received by Brazilian authorities, this database had to be supplemented with sources from each country to allow us to understand how negotiations were developed on the ground. Two media outlets were selected in each country with at least one of national coverage. ${ }^{16}$

15 On April 19, 2017, Odebrecht signed a leniency agreement with the Attorney General of the Dominican Republic. On June 13, 2017, Odebrecht signed a cooperation agreement with the Attorney General of Ecuador. On August 2, 2017, Odebrecht signed an agreement with Panama. On January 25, 2018, Odebrecht signed an agreement with the Guatemalan Justice. On February 15, 2019, Odebrecht signed a collaboration agreement with Peru (ODEBRECHT, 2021).

16 For the joint resolutions, this group aimed at analyzing Folha de S.Paulo and The Intercept Brasil, with their partner outlets. In Peru, El Comercio and IDL Reporteros and in the Dominican Republic, El Día and Diario Libre. In all of them, the research used a few keywords (such as Odebrecht, non-trial resolution, Lava Jato and other particular words for each country) and researches from 2014 to 2020 in Brazil as well as from 2016 to 2020 in Peru and the Dominican Republic. 
This paper is organized as follows: after this introduction, we turn to the Odebrecht case studies. First, the Brazil, Switzerland, and U.S. joint resolutions are explored to discuss how these modes of cooperation reinforce each other. Then, we discuss the Dominican Republic case which is, chronologically, the next agreement the company was able to achieve. The case illustrates how settlement cooperation delayed subsequent investigative cooperation or sanction-based cooperation and shaped the Dominican authorities' settlement. Next, we turn to the Peruvian case. Unlike the Dominican case, authorities relied on investigative cooperation, which seemed to pave the way for local authorities to achieve their settlement with Odebrecht. The local settlement, by its turn, affected sanctions to other companies and individuals. Then, we gather the findings of the case studies. Beyond illustrating different cooperation dynamics, we also explore the role of which sequencing plays in this intersection. The existence of previous joint resolutions affects the developments of the subsequent agreements, distinctly in each country. Finally, we conclude.

We do not claim that the modes of cooperation and how they intersect as presented in this paper capture all possible dynamics of international cooperation. However, we aim to contribute to the literature on transnational bribery by, firstly, separating and offering finegrained descriptions of how these modes of cooperation affect each other. Secondly, by using data beyond the U.S. FCPA material, we expand the descriptions of how the international regime regulates transnational bribery works, considering how the lack of a comprehensive framework for cooperation creates a different set of arrangements depending on the circumstances of the case. Lastly, by exploring the role sequencing plays in successive settlements of transnational bribery cases.

\section{The Odebrecht CASE}

The Odebrecht case is a tale of the rise and fall of a construction empire that started in Brazil in the 1940s and by late 2000s became one of the largest service exporters in the world (BRASIL, 2019, p. 4). In 2013, the Odebrecht group had more than 190,000 employees in 21 countries, revenues exceeding BRL 132 billion (approximately USD 30 billion), with numerous infrastructure projects in Latin America: roads, dams, ports, and subway lines (BRASIL, 2019, p. 4). In 2014, the Lava Jato investigation broke, tracking money laundering, embezzlement and bribes in the contracts of Petrobras, the Brazilian State-owned oil giant (LAGUNES and SVEJNAR, 2020). As the scope of the investigations grew, it became clear that Odebrecht and other major construction players in Brazil were involved in corrupt schemes that extended well beyond Petrobras. Odebrecht came to be known for establishing a complex scheme for bribery and money laundering through its now-famous Department of Structured Operations (GASPAR, 2020).

In 2016, the company decided to settle the case simultaneously with Brazilian, U.S., and Swiss authorities. Almost immediately authorities from several countries demanded access 
to the Brazil-U.S.-Switzerland agreements, leading to protests, cancellation of contracts, as well as assets' freezing throughout Latin America (GONZÁLEZ OCANTOS and BARAYBAR, 2019, PIMENTA and GREENE, 2020). The company signed new settlements with local authorities only in specific jurisdictions. In June 2019, in the middle of multiple enforcement actions, Odebrecht S.A., and its parent companies and certain subsidiaries, filed for bankruptcy (recuperação judicial) in the largest proceeding ever requested in the country (ODEBRECHT, 2019). ${ }^{17}$

In the following sections, we describe settlements signed by the company: first, the joint resolutions between Brazil, the U.S. and Switzerland, then the national agreement signed with the Dominican Republican and finally, the agreement signed with the Peruvian authorities. We look specifically at the intersection between three modes of cooperation: settlement cooperation, investigative cooperation and sanction-based cooperation, as presented in Table 1.

\section{table 1. Modes of Cooperation in Selected Odebrecht Cases}

\begin{tabular}{|c|c|c|c|c|c|}
\hline \multirow[t]{2}{*}{ AUTHORITIES } & \multirow[t]{2}{*}{ SIGNING DATE } & \multirow[t]{2}{*}{ SCOPE } & \multicolumn{3}{|c|}{ MODES OF INTERNATIONAL COOPERATION } \\
\hline & & & $\begin{array}{l}\text { SETTLEMENT } \\
\text { COOPERATION }\end{array}$ & $\begin{array}{l}\text { INVESTIGATIVE } \\
\text { COOPERATION }\end{array}$ & $\begin{array}{l}\text { SANCTION- } \\
\text { BASED } \\
\text { COOPERATION }\end{array}$ \\
\hline $\begin{array}{l}\text { BRAZIL- } \\
\text { SWITZERLAND- } \\
\text { USA }\end{array}$ & $\begin{array}{l}\text { DECEMBER 1, } \\
2016\end{array}$ & $\begin{array}{l}\text { INCLUDES } \\
\text { INFORMATION ON } \\
\text { OTHER AFFECTED } \\
\text { COUNTRIES }\end{array}$ & YES & YES & YES $^{18}$ \\
\hline $\begin{array}{l}\text { DOMINICAN } \\
\text { REPUBLIC }\end{array}$ & $\begin{array}{l}\text { APRIL 19, } \\
2017\end{array}$ & NATIONAL & NO & NO & NO \\
\hline PERU & $\begin{array}{l}\text { FEBRUARY 15, } \\
2019\end{array}$ & NATIONAL & NO & YES & NO \\
\hline
\end{tabular}

Source: Authors.

17 The General Meeting of Creditors approved the Court-Supervised Reorganization Plan of Odebrecht S.A. on April 22, 2020.

18 The joint resolutions included cooperating and agreeing to some penalties and their distribution, as described in item 2.1.2. 


\section{I The Joint Resolutions: BRAZIL-U.S.-SwitZERLAND}

Odebrecht confessed to having paid approximately USD 788 million in bribes in more than 100 infrastructure projects in twelve countries, including Angola, Argentina, Brazil, Colombia, the Dominican Republic, Ecuador, Guatemala, Mexico, Mozambique, Panama, Peru, and Venezuela. However, the initial agreements involved only three authorities: the Brazilian Federal Prosecution Service (Ministério Público Federal), the U.S. Department of Justice (DOJ) and the Swiss Office of the Attorney General (OAG).

While Odebrecht was (and still is) based in Brazil and most of its revenues and projects were related to the country, the company was considered liable under the U.S. FCPA as its agents and employees used offshore entities that were established, owned, and/or operated by individuals located in the United States to hold and disburse unrecorded funds (UNITED STATES OF AMERICA, 2016). Switzerland's jurisdiction was based on the existence of bank accounts registered in the country that facilitated payment of the bribes, as well as the movement of illicit funds between accounts in Monaco, Singapore, Luxembourg, Jersey Island, and the Guernsey Islands, among others (BRASIL, 2021b; SWITZERLAND, 2016).

\section{I . I . I INVESTIGATIVE COOPERATION}

Cooperation between authorities was crucial to the development of the Lava Jato investigations. One-third of the Brazilian Federal Prosecution Service's international legal assistance requests were sent to Switzerland (31.3\%), and the next largest number of requests was sent to the U.S. (12.9\%) (MINISTÉRIO PÚBLICO FEDERAL, 2021), as seen in Table 2 below.

While investigations in Brazil were starting to gain traction, the Swiss OAG was also conducting criminal investigations involving Petrobras and construction companies, based on reports of suspicious banking transactions from the Swiss' Money Laundering Reporting Officer. One of them is focused on tracking bribes' payments from Odebrecht S.A. and its subsidiary, Construtora Norberto Odebrecht S.A. (CNO), through several offshore accounts (SWITZERLAND, 2016).

The intense exchange of formal requests of assistance was also followed, from the early stages, by informal cooperation between authorities. In 2015, Brazilian and Swiss prosecutors exchanged information from Swiss banks on accounts of former Petrobras officials, including names or other personal requests (VASCONCELLOS, 2015). Informal exchanges between prosecutors from both countries also included a list of names of individuals with whom authorities could potentially negotiate settlements (HACKED..., 2021).

In 2015, the Swiss Federal Criminal Court established that Swiss prosecutors committed procedural irregularities by sending information on the accounts, documents, and bank statements to Brazilian prosecutors without giving suspects a chance to appeal against the exchange. The Swiss Court did not require the suspension of the cooperation, but it insisted that it should review the documents before they could be used officially in any trial, investigation, or process (HACKED..., 2021). 
Informal cooperation was also part of the relationship between Brazilian and U.S. authorities. In August 2016, a few months before the execution of the joint resolutions, Brazilian investigators requested the FBI's assistance. They were aware that Odebrecht's infamous "bribery department" used two software systems (WebDay-B and Drousys) to manage bribery and money laundering, but they were unable to break the systems' encryption. Prosecutors informally asked whether the FBI could access the encrypted systems or recommend a trusted hacker that could perform the task (HERDY, 2018). The problem of accessing the information presented in those systems persisted for some time and involved intense collaboration between the company, Brazilian and Swiss authorities (ARQUIVO..., 2021; MINISTRO, 2021).

Despite the extensive use of formal mutual legal assistance requests, some Brazilian law enforcers claimed that sometimes the formal processes were considerably slow, clashing with the timing and sensitivity of the investigation. ${ }^{19}$ They argued that prior and informal contact with their counterparts was necessary to properly contact central authorities. ${ }^{20}$ In addition, using the formal instruments would require prosecutors to inform other authorities in the Ministry of Justice, and there were concerns regarding possible leaks. ${ }^{21}$ The accused argued that authorities receiving evidence through informal proceedings - even if only to further specify formal requests - would violate due process and fairness in name of an investigative shortcut (VASCONCELLOS, 2015).

Intense investigative cooperation, formal and informal, allowed for the advancement of the Odebrecht investigations, and it is reasonable to assume that the relationships developed between authorities enabled the joint resolutions with the company.

19 As seen in a series of messages from Brazilian prosecutors, members of the Lava Jato Task Force were leaked by The Intercept and other media partners (AS MENSAGENS..., 2019). After inquiries from the press, Brazilian prosecutors highlighted that "exchange of information with foreign authorities was essential to ensure efficiency and positive results for the investigation” (RODAS, 2021).

20 The Brazilian Prosecutor General Office (PGR) expressly stated that "such prior contacts are encouraged by international forums, such as the United Nations Office on Drugs and Crime (UNODC), as measures that must precede formal requests" (VASCONCELLOS, 2015).

21 For most mutual legal assistance treaties, the DRCI (Department of Asset Recovery and International Legal Cooperation), within the Ministry of Justice, acts as the Brazilian central authority, by receiving and sending requests for cooperation. In parallel, the Secretariat for International Cooperation (SCI) of the Office of the Prosecutor General (PGR) is responsible for executing the requests received by the DRCI from other countries. The SCI also articulates some of the informal cooperation initiatives, as part of the international enforcers' networks or exchanges or by signing "memoranda of understanding” with direct counterparts, while informing the DRCI. According to data released by the PGR and updated on January 21, 2021, the SCI has received passive requests for legal cooperation from 40 countries and the DRCI has sent active orders to 61 nations (BRASIL, 2021b). 
I . i . 2.The Joint Resolutions: Convergence and Divergence

The December 1, 2016, joint resolutions reflect each authority's domestic legal framework. The Brazilian Federal Prosecution Service signed a leniency agreement with Odebrecht S.A. ${ }^{22}$ In the U.S., Odebrecht pleaded guilty to a one-count criminal information charging the company with conspiracy to violate the anti-bribery provisions of the U.S. FCPA (UNITED STATES OF AMERICA, 2016). Odebrecht also settled with the Swiss OAG, as Odebrecht S.A. and Construtora Norberto Odebrecht S. A. were considered guilty of a violation of Swiss corporate criminal law (Art. 102, § 2, Swiss Criminal Code), in which they did not take all reasonable compliance measures required to prevent the offenses of bribing foreign public officials (Art. 322 septies) and money laundering (Art. 305 bis).

These settlements were signed separately, however, some of the provisions were coordinated. Both the U.S. DOJ and the Brazilian authorities completed independent analyses of the company's ability to pay the criminal penalty (§21(c) of the plea agreement). The analysis determined the reduction of the total criminal penalty from initially USD 4,503,600,000 to USD 2,600,000,000 (UNITED STATES OF AMERICA, 2016). As per the agreement between authorities ( $\S 21(\mathrm{~d})$ ), the Brazilian authorities would receive USD 2,391 billion in installments, starting on December 31, 2021, and the U.S. and Switzerland would divide the remainder (approximately 10\% each).

Following the financial decline of the group, there was another steep reduction in the U.S. financial penalty, from USD 260 million to USD 93 million (UNITED STATES OF AMERICA, 2017). The United States received less than what was originally calculated, but the joint resolutions has been completely paid to date. The remaining USD 116 million was allocated to the Swiss authorities (UNITED STATES OF AMERICA, 2017). ${ }^{\mathbf{2 3}}$

Beyond coordinating financial sanctions, both the United States (§ 30-32) and Brazil (6th Clause, $\mathrm{X}$ ) included matching compliance obligations. The company had to retain an independent compliance monitor for three years. This is a common obligation in FCPA practice, but it was an innovation in the Brazilian system. Independent monitorships are not regulated

22 There is no criminal liability for corporations in Brazil. The leniency agreements lower administrative and civil liabilities imposed on companies by the Brazilian Anti-Corruption Act (Law No. 12,846/13). There is a dispute of competence between Brazilian authorities to sign these agreements. Therefore, in 2018, Odebrecht S.A. signed a new leniency agreement with other Brazilian authorities - the Brazilian Office of the Comptroller General (CGU) and the Attorney General's Office (AGU). In the new leniency agreement, the parties reached the amount of BRL 2.7 billion (approximately USD 700 million), as well as crediting clauses to deduct amounts paid in other agreements.

23 According to Makinwa and Søreide (2018, p. 350) the actual fine imposed by Switzerland was deeply lower, as the Swiss law has severe limitations to the fines it can apply, when compared to other countries. 
by law and were not used in other corporate agreements before the Odebrecht case (PIMENTA, 2020). The introduction of corporate monitorship in the Brazilian agreement was possibly a byproduct of the joint resolutions.

The U.S. and Brazilian settlements also included some obligations for the company to cooperate in other ongoing domestic and foreign investigations. Under the U.S. plea agreement, the defendant agrees to any disclosure to foreign authorities at the discretion of the DOJ Fraud Section and the United States' Attorney Office of the Eastern District of New York (EDNY), except for evidence protected by attorney-client privilege and other applicable provisions. The Brazilian leniency agreement also includes an obligation to cooperate with foreign authorities (Clause 21). The agreement, however, expressly allows the company to refrain from cooperating not only to abide by other rules and regulations but also to prevent the use of information to further foreign investigations and sanctions against the company and the executives which signed non-trial agreements with the Brazilian authorities. It also includes the possibility of the MPF requiring foreign authorities to sign a declaration ensuring the respect of such restrictions, representing a topic that impacted investigative cooperation, as seen in the Peruvian case below.

The Brazil, Switzerland, and U.S. joint resolutions have been praised as an example of settlement cooperation, organized in three separate agreements with some matching provisions, especially the fine paid, their distribution between the authorities, and some compliance obligations concerning Brazil and the U.S.

Some divergence between the authorities remained, notably in addressing how much publicity to give to the agreements. Soon after the parties signed the agreements, the DOJ released public statements on the Odebrecht transnational scheme, as it traditionally does in its cases. The publicity given by the DOJ contrasted with the non-trial agreement signed with the Brazilian Federal Prosecution Service. Clause 19 of the Brazilian agreement provided six months of total confidentiality to the confessed practices that directly involved foreign public agents (BRASIL, 2016b). It would give the company time to reach out to other authorities and start a negotiation process before the Public Prosecutor's Office resumed investigative cooperation with others.

The publicity by the DOJ was sufficient to send shock waves through Latin America. It led to investigations, asset freezing, contract annulments, as well as public demonstrations. The DOJ's statement also ignited requests for investigative cooperation from other authorities, specially directed to Brazil. ${ }^{24}$ The requests were based on the international framework 
for legal assistance, using the same instruments that paved the way for the first joint resolutions (OECD, 2019, p. 196).

\section{i.2. Commitment to Subsequent Cooperation: The 2017 Brasília Declaration}

Brazilian authorities started to receive multiple requests for cooperation related to the Odebrecht case, however, prosecutors were bound by the six months of confidentiality. Nevertheless, on February 16, 2017, the Attorneys and General Prosecutors of Argentina, Brazil, Chile, Colombia, Ecuador, Mexico, Panama, Peru, Portugal, the Dominican Republic and Venezuela agreed to cooperate under the auspices of the "Brasília Declaration on International Legal Cooperation against Corruption.”

The Brasília Declaration outlines commitments for international legal assistance in investigations, involving alleged crimes committed by or through the company Odebrecht, its directors and employees, as well as by other companies investigated in the Lava Jato case in several countries (ARGENTINA, 2017). The signatory parties of the declaration committed to offering the widest, fastest and most effective international legal cooperation in the Odebrecht and Lava Jato cases. It encourages prosecutors to cooperate during investigations to obtain evidence, through informal mechanisms such as spontaneous communications and information-sharing. It also stressed the importance of sanction-based cooperation, regarding asset recovery and full reparation of damages caused by illicit acts, including the payment of fines.

The Declaration is an attempt to enhance investigative cooperation and sanction-based cooperation and to include other affected countries in the investigation. It supports the same strategy that made the joint resolutions between the U.S., Switzerland, and Brazil possible: a combination of formal and informal cooperation.

As we will further explore in the cases of the Dominican Republic and Peru, the joint resolutions and the framework established by the Brasília Declaration influenced subsequent investigative cooperation and settlement negotiations.

\section{I.3. Dominican Republic}

As soon as information on the Odebrecht scandal surfaced, thousands marched in the streets of Santo Domingo, in the Dominican Republic. The movement La Marcha Verde demanded accountability, as well as the return of the proceeds of corruption to Dominican society. The illicit transactions of Odebrecht in the Dominican Republic started in the Hipólito Mejía

Peru was the country with the largest number of demands, accounting $41.2 \%$ of the requests, followed by Switzerland (36.8\%) (BRASIL, 2021b). Lava Jato is broader than the Odebrecht case, but it still gives a dimension of how important international cooperation to the investigation was. 
government, from 2000 to 2004. Odebrecht hired the businessman Ángel Rondón to secure improper advantages in the Dominican government. Rondón acted as an intermediary between the company and the Dominican public officials. For at least 18 years, he distributed bribe payments to members of the Executive and Legislative branches in that country, in exchange for awarding projects to Odebrecht. Allegedly, the company paid approximately $3 \%$ of the amount of the construction projects in bribes. The Hermanas Mirabal's and Samanás aqueducts and Punta Catalina's thermoelectric central power plant were potentially affected projects (JOTA and TRANSPARENCIA INTERNACIONAL BRASIL, 2019).

The Dominican Republic was also central for the financial flows of Odebrecht's corruption scheme. Bribes were originally transferred through accounts "mostly opened at Citibank in New York, but also at Crédit Agricole Suisse in Geneva, and at Banco Popular Dominicano in the Dominican Republic." ${ }^{25}$ Moreover, after the Lava Jato investigations started, the Department of Structured Operations' hardware was moved to the Dominican Republic to avoid raids from the Brazilian authorities. Executives from the company briefly considered maintaining operations from there (GASPAR, 2020, p. 398).

\section{I $\cdot 3 \cdot$ I . Attempted Investigative Cooperation}

To clarify the local implications of Odebrecht's scheme, the Attorney General's Office of the Dominican Republic sent investigative cooperation requests to the Brazilian and U.S. authorities. ${ }^{26}$ After all, the DOJ's public release alluded to the payment of USD 92 million to public officials in the Dominican Republic. However, the requests were not answered immediately. Brazilian authorities remained bound by their agreement with the company to wait for six months before disclosing information (REPÚBLICA DOMINICANA, 2017, p. 4).

The Dominican authorities negotiated a settlement with Odebrecht without receiving the information requested from Brazilian authorities. On March 16, 2017, the holding company of the group signed an agreement with the Attorney General of the Dominican Republic, later ratified by the Third Court of Santo Domingo on April 19, 2017 (REPÚBLICA DOMINICANA, 2017).

25 Check Criminal procedure n. 5036528-23.2015.4.04.7000/PR (BRASIL, 2016a).

26 Which included two requests to the Brazilian Department of Asset Recovery and International Legal Cooperation (DRCI), one rogatory letter to the Brazilian Federal Central Authority (ACAF), one request to the U.S. Attorney General's Office and one rogatory letter to the U.S. Department of Justice (REPÚBLICA DOMINICANA, 2017, p. 4). 
i 3.2. The Dominican Republic Agreement

The agreement with the General Attorney of the Dominican Republic highlighted the country's commitment to the Inter-American Convention against Corruption (IACAC) and its local anti-bribery law (n. 448-6). The document was based on the Dominican Republic's Criminal Procedure Code (Articles 370.6, 369-373) and on the Law n. 448-6. It required the company to share relevant and accurate information with the Dominican authorities. It explicitly alluded to the annexes from the joint resolutions signed with Brazilian and U.S. authorities related to the Dominican Republic (REPÚBLICA DOMINICANA, 2017, p. 45). The company agreed to pay USD 184 million in 8 annual installments (from 2017 to 2025) for damages. The amount is roughly twice as the bribes indicated in the joint resolutions (REPÚBLICA DOMINICANA, 2017, p. 47). Even if no further evidence was shared before the execution of the Dominican settlement, the facts and amounts declared and negotiated between the company and the Brazilian, Swiss, and U.S. authorities may appear to have been used as a reference.

\section{I $3 \cdot 3 \cdot$ After the Agreement}

On August 1st, 2018, the Attorney General's Office of the Dominican Republic announced that the first and the second installments, each one of USD 30 million, had been paid in the special account held by the Attorney General's Office (PROCURADURÍA..., 2018). However, in 2019, payments ceased. Instead, the Dominican Republic was included on the list of creditors in Odebrecht's bankruptcy proceedings filed in Brazil (GENTILE and LANDIM, 2019), as the only sovereign country. According to the company, while in other countries the settlements were signed with construction and engineering companies of the group, in the Dominican Republic the agreement was signed with the holding company that agreed to the bankruptcy filings (GENTILE and LANDIM, 2019). ${ }^{27}$ The country constested its inclusion as a creditor and vowed to reopen lawsuits against Odebrecht (GENTILE and LANDIM, 2019).

In the end, the first agreement after the 2016 joint resolutions was a quick win for local prosecutors. Obtaining evidence from the company could be crucial to investigate individuals implicated in the scheme. To date, the Dominican Republic has issued sixteen indictments in the case (GONZÁLEZ OCANTOS and BARAYBAR, 2019), however, individual sanctions are still pending (ESTADOS, 2020). While Dominican authorities were not part of the joint resolutions and did not rely on international cooperation to negotiate the agree-

ment, important provisions (such as the scope of evidence to be shared and the amounts to be paid) were shaped by the previous existence of the joint resolutions. eral meeting of creditors (ODEBRECHT, 2019). The approval of the competent judge is still pending. 


\section{I.4. Peru}

Odebrecht had ambitious construction projects in Peru, including highways, dams and the Lima subway. The company had a strong connection to the Peruvian political elite and contributed to all parties and major leaders. Currently, all the elected presidents since Fujimori's dictatorship have been implicated in the Odebrecht scandal and the investigations continue to unfold (PIMENTA and GREENE, 2020).

The joint resolutions divided the public opinion in the country. As a response, in February 2017, then-President Pedro Pablo Kuczynski issued the so called Urgent Decree 003-2017 (Decreto de Urgencia). Companies that had admitted offenses beyond Peru's borders were prohibited from sending any sums overseas in order to preserve assets for reparations in the country. ${ }^{28}$ The Decree led to a total freeze of Odebrecht's accounts in the country and the company was banned from public contracts, including those already underway. Interrupted payments to suppliers affected around 250 projects with around 50,000 employees (PIMENTA and GREENE, 2020). In 2018, the Decree was replaced by a new Law $(30,737)$ that eased some government's requirements for asset reparations and allowed settlements with companies. Later in May, the Decree n. 096-2018-EF further specified procedures for estimating State reparation claims.

\section{i.4. I Investigative CoOperation}

Enforcement in Peru was supported by intense investigative cooperation between Peruvian and Brazilian authorities. Early in 2017, the Prosecutor General of Brazil and Peru signed an agreement to increase cooperation between the countries, as well as exchanges of information (BRAZIL..., 2017). From that point on, exchanges between the countries increased significantly. By 2021, Peru had made over 270 requests for international cooperation to Brazil, as seen in Table 2 below.

28 Plus, either the sale or divestment from these companies were made conditional on government's approval. 
INTERNATIONAL COOPERATION AND NEGOTIATED SETTLEMENTS FOR TRANSNATIONAL BRIBERY :

TABLE 2. REQUESTS FOR MUTUAL LEGAL ASSISTANCE IN LAVA JATO RECEIVED OR SENT BY BRAZILIAN AUTHORITIES

REQUESTS SENT

\begin{tabular}{llc}
\hline USA & 77 & 24 \\
\hline SWITZERLAND & 175 & 123 \\
\hline PERU & 6 & 274 \\
\hline DOMINICAN REPUBLIC & 2 & 4 \\
\hline
\end{tabular}

The existence of the previous settlements affected the investigative cooperation between Brazil and Peru. This can be illustrated by one particular episode. On May 15, 2017, key executives from Odebrecht including the former CEO Marcelo Odebrecht and Jorge Barata, which was the main executive in charge of the Peruvian operations, testified before the Peruvian authorities with the assistance of the Brazilian Public Prosecutor. The Brazilian authorities had already executed non-trial agreements with the company and its main executives; therefore, these individuals were cooperating with them. By testifying to Peruvian authorities, they risked eliciting self-incriminating evidence without the same kind of protection they had in Brazil. A possible alternative could be to remain silent and withhold information, however, it would have been contrary to the obligations of extensive cooperation they assumed before the Brazilian authorities.

Aiming to solve this conundrum, the Brazilian Federal Prosecution Service, as provided in the agreement signed with Odebrecht, requested the Peruvian authorities to sign a memorandum confirming that they would not use the information against any of the individuals or the companies which have previously signed non-trial agreements. ${ }^{29}$ This unusual arrangement between Brazilian and Peruvian authorities preserved the former's commitment to the agreements and allowed the latter to access the requested information.

This raised some controversy between members of the Peruvian Special Prosecution team. Some of them had reservations about granting immunity to the individuals upfront (GONZÁLEZ OCANTOS and BARAYBAR, 2019). Subsequently, these authorities decided to use Marcelo Odebrecht's deposition to block assets and present criminal charges

29 Check PERU and BRAZIL (2017) and GORRITI (2017). 
against the other collaborator, Jorge Barata (GORRITI, 2017). The Brazilian Public Prosecutor's Office reacted. In 2018, Brazilian Prosecutors backed the decision made by the individuals not to testify to Peruvian authorities that did not sign the memorandum (MELLA, 2018; VARADOS, 2018).

These conflicts had two effects. First they pressured Peruvian authorities to sign a local settlement with the company and its individuals. Secondly they contributed to the ouster of the Special Prosecution team leader Mr. Hamilton Castro, in 2018 (RODRÍGUEZ-OLIVARI, 2020). Mr. Rafael Vela, the new leader, signed the memorandum and cooperation between the countries resumed.

\section{I .4. 2 The Peruvian Agreement}

Peru enacted the Corporate Liability Law n. 30.424 (CLL) on March 17, 2016. The CLL creates administrative liability for foreign and domestic bribery, money laundering, and other offenses, and entered into force on January $1^{\text {st }}, 2018 .^{30}$ Peru also adopted Law No. 30.737 on March 12, 2018, which ensures immediate payment of civil remedies in favor of the Peruvian State in cases of corruption and related crimes. In addition, the Criminal Code (CC) also applies to legal persons in Peru. The investigation and prosecution of legal persons in Peru take place within the framework of criminal proceedings (OECD, 2019, p. 24).

Odebrecht started negotiating an agreement with the Peruvian authorities in 2017. We accessed the Draft Collaboration and Benefits Agreement (Acuerdo Preparatório de Colaboración $y$ Beneficios) signed on December $7^{\text {th }}, 2018$ through public information released in the press. The Agreement sets the date for the final document to be submitted for ratification by the Judiciary on January 11, 2019 (SE FILTRÓ..., 2019).

The Draft Agreement was signed by the Special Prosecution Team and the Attorney General's Office of Peru and extended to Constructora Norberto Odebrecht S.A. and Sucursal Perú, as well as to Odebrecht Peru Ingeniería y Construcciones SAC. ${ }^{31}$ It was based on: i) effective collaboration (colaboración eficaz), a provision in the Criminal Procedure Code (Art. 475(1)) in which the accused cooperates with the authorities in return for reduced sanctions; ii) payment of civil remedies in favor of the Peruvian State (Law No. 30.737); and iii) corporate liability (CLL). ${ }^{32}$

30 It was subsequently amended by Legislative Decree n. 1.352/2017 and Law n. 30.835/2018.

31 This was not the final agreement signed between the authorities, but all the information presented has been checked in other sources and seems to be reliable.

32 There are currently three options available for resolving foreign bribery cases without a trial in the country's legal system: (1) an early termination of proceedings is similar to an agreement formalized in a preparatory investigation in other jurisdictions (terminación anticipada); (2) an early conclusion to a trial is similar 
The Preparatory Agreement was limited to the discussion of four specific cases regarding six contracts with the Peruvian State: the Lima Subway, two projects related to the InterOceanic highway (Carretera Interoceánica Sur tramos 2 y 3), the Costa Verde Callao highway and the highway Vía de Evitamiento Cusco (PERU, 2018; EL ACUERDO, 2018). According to the agreement, Odebrecht would submit evidence contained in the Structured Operations Department's software related to the projects, as well as to any wrongdoing within the jurisdiction of the Peruvian State (PERU, 2018; EL ACUERDO, 2018).

Such agreement established PEN 610 million as a civil reparation payment (approximately USD 179 million), in 15 annual installments, starting with PEN 80 million in 2019 (USD 23 million). Moreover, the company agreed to pay PEN 450 million for tax evasion (USD 130 million).

In June 2019, the corporate agreement was approved by the Peruvian judiciary. The amounts already paid are currently considered as the largest sums ever recovered by Peruvian authorities (RODRÍGUEZ-OLIVARI, 2020). It was not, however, the end of the company's troubles.

\section{I .4 3. After the Agreement}

Less than ten days after the approval of the agreement in 2019, the International Consortium on Investigative Journalism (ICIJ) released information concerning bribes allegedly paid on other five Peruvian projects which were not initially included in either the joint resolutions or the Peruvian agreement (MELLA and GORRITI, 2019). This included payments of USD 3 million for the Gasoducto Sur Peruano, one of the largest infrastructure projects in the country. This fueled discontentment the agreement. However, the Peruvian agreement had clauses that allowed the company to bring new evidence of crimes and renegotiate reparations, with the same guarantees, if it could prove that it acted in good faith (OBSTRUCCIÓN EFICAZ, 2019).

In 2020, on another episode, Ollanta Humala, one of Peru's former presidents under investigation, bypassed the local agreement to obtain further evidence. He filed a petition before the Brazilian Supreme Court (STF) to access information provided by Odebrecht to the Brazilian Public Prosecution Office, including the information from the Department of Structured Operations. The Brazilian agreement covers wrongdoings in Brazil and other countries which are not related to wrongdoings in Peru, thus, it includes executives that are not part of the Peruvian agreement. Mr. Humala's request aimed at ensuring that all the

to an early termination, but it occurs at a later stage of the proceedings (conclusión anticipada del juicio); and

(3) effective collaboration is an arrangement in which the offender co-operates with the authorities with the aim of a more lenient sentence (colaboración eficaz) (OECD, 2019, p. 27-28). 
relevant information was shared with Peru and not only the parts that benefitted the prosecution. Instead of directing his claim to the Peruvian authorities, he turned to the Brazilian court based on due process principles.

The Brazilian Supreme Court had to decide whether to preserve the secrecy of the evidence submitted in the Brazilian agreement over the right to due process of an individual potentially affected by it. The court decided to uphold the right to due process (OBSTRUCCIÓN EFICAZ, 2019). The decision benefitted one individual but it could discourage the company's settlements in Brazil and Peru, as well as any further investigative cooperation. The fact that individuals from other countries can obtain the full domain of evidence by taking the case to the Brazilian Supreme Court lowers the assurances that Brazilian authorities provide a negotiating company. It also affects the assurances given by non-Brazilian authorities when negotiating a local agreement. Moreover, the decision decreases the attractiveness of international cooperation in general as it enables bypassing authorities in charge of investigative cooperation.

The Peruvian Agreement has had its share of controversy. In a survey, only half of Peruvians expressed approval (RODRÍGUEZ-OLIVARI, 2020, p. 173). Nonetheless, it is possible to speculate that the agreement had a positive spillover effect. It allowed investigative cooperation to move forward under the leadership of Mr. Vela. Many documents were submitted to the authorities and thirty-four indictments were issued (GONZÁLEZ OCANTOS and BARAYBAR, 2019). In addition, the existence of an agreement with Odebrecht led the way for other companies to come forward. Graña y Montero, one of the most important Peruvian construction companies, started to cooperate by expanding on the information given by Odebrecht (GRAÑA, 2019).

\section{Modes of Cooperation in The Odebrecht Settlements}

This section summarizes the findings of the cases, discussing the role sequencing plays in the dynamics of cooperation. Settlement cooperation affects subsequent investigative cooperation and shapes the local agreements that were signed later.

The joint resolutions signed in December 2016 by Swiss, Brazilian and U.S. authorities illustrate the benefits of both settlement cooperation and investigative cooperation. They have been highly praised as examples of how to avoid duplication of penalties that can lead to overde-

terrence or wasted public resources. ${ }^{33}$ Brazil, Switzerland and the U.S. each made a distinct

33 In the press conference in 2016, U.S. authorities considered "Such brazen wrongdoing calls for a strong response from law enforcement. It was possible to evidence a strong effort with our colleagues in Brazil and Switzerland. I hope that today's action will serve as a model for future efforts" (UNITED STATES OF 
contribution to the enforcement effort. Odebrecht's headquarters and the Department of Structured Operations were based in Brazil and much of the evidence was in the country. Brazilian authorities had the technical capacity and built the political climate to sanction one of its largest private conglomerates. Switzerland had valuable information regarding banking accounts and the software used in the scheme. Some accounts were also located in the U.S., but it is possible speculate that its contribution lay in expertise associated with its role as the strongest enforcer of prohibitions on transnational bribery, with an established practice of imposing high penalties. Each country was able to increase at least one of two assets (information and sanctions) (DAVIS, 2016) to justify (i) the additional time (more rounds of negotiation), (ii) costs (lower returns of assets/penalties for a single jurisdiction), and (iii) risks of including another party (for instance, of leakage on sensitive information or the difficulty of finding cohesion between different legal frameworks). Our research also reveals that the negotiation of the joint resolutions was preceded by substantial investigative cooperation, both formal and informal, by highlighting how the two modes of cooperation can reinforce one another.

The joint resolutions did not include the other 8 countries affected by the Odebrecht scheme. The subsequent Brasília Declaration represented a commitment to investigative and sanction-based cooperation among other affected countries. By establishing direct links between the Prosecutors General of other countries, the initiative most likely facilitated subsequent cooperation, but the existence of the joint resolutions conditioned the subsequent interactions.

The publicity given by U.S. enforcers allowed other affected countries to discover illicits conducted within their borders or that involved their interests. It lowered the costs of uncovering wrongdoing which can be interpreted as a positive feature of transnational law enforcement (DAVIS, JORGE and MACHADO, 2015). However, the Dominican case suggests that this publicity may be sufficient for authorities to abandon investigative cooperation, due to the popular pressure that the publication of such information generates. Dominican authorities decided not to wait for the cooperation of other countries to settle the local case.

The Dominican Republic did not rely on investigative or sanction-based cooperation, but it explicitly referred to the joint resolutions to establish the scope of the information to be disclosed and the reparations Odebrecht had to pay. This could be referenced as a carbon copy agreement as discussed in the introduction. The Dominican Republic agreement would fit this description only if the information obtained by the authorities did not advance domestic accountability processes, such as to recover assets (which are currently endangered by

AMERICA, 2016b). Later, the Brazilian, Swiss, and U.S. cooperation is cited in the DOJ Anti-Piling-On Policy as an example (UNITED STATES OF AMERICA, 2020). 
the group's restructuring) or to further individuals' sanctions which has not being materialized so far.

The Peruvian case illustrates a different dynamic. It exemplifies how investigative cooperation was crucial to build the next steps of investigations as well as the local corporate agreement. Brazilian authorities developed intense investigative cooperation with the Peruvian authorities. However, as the former were bound to the terms of their own agreement, they closely monitored how the information they provided was used by the Peruvian authorities to avoid overstepping the limits of the agreement they signed with the company. This exemplifies how the existence of a prior settlement shapes further investigative cooperation. In addition, this dynamic might have pushed Peruvian authorities to negotiate an agreement with the company.

The Peruvian agreement shows how investigative cooperation can support a local settlement even in the absence of a settlement cooperation. It shows that valuable information and additional reparation can be elicited after joint resolutions are executed. Further local agreements can be interesting to those that do not have the immediate bargaining power to participate on the negotiations of the joint resolutions. In this case, investigative cooperation can supplement the joint resolutions by allowing more countries to develop their accountability processes, even if shaped by prior resolutions. It could also be a warning example against a simplistic view of sequencing in the execution of negotiated settlements. Successive deals may not be a mere pile-on or carbon copy agreements.

In the Dominican and the Peruvian case, the local agreements may have acted as a substitute for sanction-based cooperation, involving direct negotiations with the company over fines, reparations and payment schedules. However, when there is no sanction-based or settlement coordination, the financial sanctions imposed by different authorities may add up to significant amounts, straining the company's resources and potentially threatening its survival.

Finally, in our analysis, we found interesting data on how investigative cooperation interacts with domestic institutional multiplicity. This concept relates to a multitude of institutions within one country monitoring, investigating and sanctioning individuals and companies based on different legal accountability processes, such as criminal or administrative proceedings (for a discussion in the Brazilian context, see PRADO and CORNELIUS, 2020; MACHADO and PASCHOAL, 2016). First, consider the attempts of the Brazilian Federal Prosecution Service to bypass the Brazilian central authority through informal exchanges. Second, recall former President Humala's attempt to circumvent the Peruvian authorities and demand information from the Brazilian authorities. In each case, actors in one system used authorities in another system to pursue their own agendas. The lack of a regulatory framework governing the dynamics and intersections of cooperation, combined with domestic institutional multiplicity, increases the number of actors that can interact in different and sometimes unexpected ways in the course of international cooperation, further increasing the difficulty of predicting the effects of various modes of cooperation. These dynamics have 
not been previously mapped neither by scholars interested in domestic institutional multiplicity nor by those interested in multi-jurisdictional enforcement.

\section{CONCLUSION}

This paper provides concrete and nuanced examples of how investigative, sanction-based and settlement cooperation can reinforce as well as undermine each one by analyzing Odebrecht settlements in Brazil, Switzerland, the U.S., the Dominican Republic and Peru. Moreover, the analysis highlights the role sequencing plays in these cooperation dynamics as well as the fact that domestic multiplicity may also impact international cooperation.

As the Odebrecht case continues to unfold, further research should include other countries or further evaluate the local accountability process beyond the settlement with the company. On a more abstract level, further research could attempt to model the conditions under which these modes of cooperation are likely to interact positively or negatively. This paper aims at serving as a stepping-stone towards more fine-grained descriptions of cooperation in transnational bribery cases, especially in the increasing reality of multiple countries willing to enforce their national and transnational provisions through the use of negotiated settlements.

\section{ACKNOWLEDGEMENTS}

The authors wish to thank two anonymous reviewers, guest editors Kevin Davis, Mariana Prado, Marta Machado, and Catarina Barbieri, the editor-in-chief of Revista Direito $\mathrm{GV}$, as well as all participants of the Law \& Systemic Corruption Seminar organized in August 2020 at São Paulo Law School (FGV DIREITO SP). They also thank Michelle Ratton Sanchez Badin and Arthur Badin for kick-off exchanges around this topic. All errors and imprecisions are of authors' own.

\section{REFERENCES}

ABBOTT, Kenneth W.; SNIDAL, Duncan. Values and Interests: International Legalization in the Fight Against Corruption. The Journal of Legal Studies, v. 31, n. S1, p. S141-S177, 2002. 
ALTER, Karen J.; RAUSTIALA, Kal. The Rise of International Regime Complexity. Annual Review of Law and Social Science, v. 14, p. 329-349, 2018.

ÁLVAREZ, María Isabel. Odebrecht pidió que se ejecute sentencia de colaboración eficaz. El Comercio. 2019. Available at: https://elcomercio.pe/politica/odebrecht-pidio-que-se-ejecute-sentencia-decolaboracion-eficaz-noticia/?ref=ecr. Accessed on: April 20, 2021.

ARGENTINA; BRASIL; CHILE; COLÔMBIA; EQUADOR; MÉXICO; PANAMÁ; PERU; PORTUGAL; REPÚBLICA DOMINICANA; VENEZUELA. Declaração de Brasília sobre a Cooperação Jurídica Internacional contra a Corrupção. Brasília, 2017. Available at: http: / /www.Public Prosecutor’s Office. mp.br/pgr/documentos/declaracao-de-brasilia-1.pdf. Accessed on: April 20, 2021.

ARLEN, Jennifer. The Potential Promise and Perils of Introducing Deferred Prosecution Agreements Outside the U.S. In: SØREIDE, Tina; MAKINWA, Abiola (ed.). Negotiated Settlements in Bribery Cases. Edward Elgar, 2020.

ARLEN, Jennifer; BUELL, Samuel W. The Law of Corporate Investigations and the Global Expansion of Corporate Criminal Enforcement. Southern California Law Review, v. 93, p. 697, 2019.

ARQUIVO da Odebrecht era levado em sacola de mercado: “Tá aí a cadeia de custódia”. Consultor Jurídico. 2021. Available at: https: / / www.conjur.com.br/2021-fev-08/arquivo-odebrecht-levado-sacolas-taai-cadeia-custodia. Accessed on: July 16, 2021.

AS MENSAGENS secretas da Lava Jato. The Intercept_Brasil. 2019. Available at: https:// theintercept. com/2020/01/20/linha-do-tempo-vaza-jato/. Accessed on: April 20, 2021.

AXELROD, Robert M. The Evolution of Cooperation. Rev. ed. New York: Basic Books, 2006.

BOUTROS, Andrew S.; FUNK, T. Markus. Carbon Copy Prosecutions: A Growing Anticorruption Phenomenon in a Shrinking World. University of Chicago Legal Forum, v. 2012, art. 12, 2012.

BRASIL. Justiça Federal (13 ${ }^{\mathrm{a}}$ Vara Criminal). Ação criminal n. 5036528-23.2015.4.04.7000/PR. Autores: Ministério Público Federal; Petróleo Brasileiro S/A. Réus: Araújo; Duque; Costa; Da Silva; Odebrecht; Freitas Filho; Rocha; Oliveira; De Alencar; Boghossian e Youssef. Juiz Sérgio Moro. 08.05.2016. Curitiba. 2016a.

BRASIL. Ministério da Justiça e Segurança Pública. Acordos bilaterais em matéria penal. 2021a. Available at: https://www.justica.gov.br/sua-protecao/cooperacao-internacional/cooperacao-juridica-internacionalem-materia-penal/acordos-internacionais/acordos-bilaterais-1. Accessed on: April 20, 2021. 
BRASIL. Ministério Público Federal. Exterior: Caso Lava Jato. 2021b. Available at: http: / /www.Public Prosecutor's Office.mp.br/grandes-casos/lava-jato/efeitos-no-exterior. Accessed on: April 20, 2021.

BRASIL. Ministério Público Federal; Odebrecht S.A. Termo de Acordo de Leniência. 2016b. Available at: https: / / www.conjur.com.br/dl/acordo-leniencia-odebrecht-Public Prosecutor's Office.pdf. Accessed on: April 20, 2021.

BRASIL. Procuradoria Geral da República. Petição n. 6729. 13.03.2017. Brasília. 2017. Available at: http:/ / estaticog1.globo.com/2017/politica/lista-de-fachin/PET_6729.pdf. Accessed on:April 20, 2021.

BRASIL. Procuradoria da República no Paraná. News release. PUBLIC PROSECUTOR'S OFFICE firma acordos de leniência com Odebrecht e Braskem. 2016c. Available at: http: //www.Public Prosecutor's Office.mp.br/ $\mathrm{pr} /$ sala-de-imprensa/noticias-pr/Public Prosecutor's Office-firma-acordos-de-leniencia-com-odebrechte-braskem. Accessed on: April 20, 2021.

BRASIL. Tribunal de Justiça de São Paulo ( $1^{a}$ Vara de Falências). Pedido de Recuperação Judicial Grupo Odebrecht no 1057756-77.2019.8.26.0100. 17.07.2019. São Paulo. 2019.

BRASIL. Supremo Tribunal Federal. Agravo Regimental na Petição n. 7.494. Relator: Min. Edson Fachin. Distrito Federal. 2020. Available at: http://portal.stf.jSA.br/processos/detalhe.asp?incidente= 5357864. Accessed on: April 20, 2021.

BRAZIL and Peru to Cooperate on Corruption Investigations. Reuters. 2017. Available at: https:// www.reuters.com/article/brazil-peru-corruption-idUSL5N1F33YB. Accessed on: April 20, 2021.

BREWSTER, Rachel. Enforcing the FCPA: International Resonance and Domestic Strategy. Virginia Law Review, v. 103, n. 8, p. 1611-1682, Dec. 2017.

BREWSTER, Rachel; BUELL, Samuel W. The Market for Global Anticorruption Enforcement. Law and Contemporary Problems, v. 80, n. 1, p. 193-214, 29 Mar. 2017.

CARSON, Lindsey D.; PRADO, Mariana Mota. Using Institutional Multiplicity to Address Corruption as a Collective Action Problem: Lessons from the Brazilian Case. The Quarterly Review of Economics and Finance, v. 62, p. 56-65, 2016.

CASSIN, Richard L. DOJ Reduces Odebrecht Penalties, We Revise the Top Ten List. The FCPA Blog. 14.04.2017. Available at: https: / fcpablog.com/2017/04/14/doj-reduces-odebrecht-penalties-werevise-the-top-ten-list/. Accessed on: April 20, 2021. 
CRUZ, Rodrigo. ¿Por qué es tan importante abrir MyWebDayB, el software de los sobornos de Odebrecht? El Comercio. 2020. Available at: https:/ / elcomercio.pe/politica/por-que-es-tan-importante-abrir-mywebdayb-el-software-de-los-sobornos-de-odebrecht-noticia/?ref=ecr. Accessed on: April 20, 2021.

DANDURAND, Yvon; COLOMBO, Gherardo; PASSAS, Nikos. Measures and Mechanisms to Strengthen International Cooperation among Prosecution Services. Crime, Law and Social Change, v. 47, n. 4-5, p. 261-289, 2007.

DAVIS, Kevin E. Multijurisdictional Enforcement Games. New York University Law and Economics Working Papers, Paper n. 438, 2016. Available at: http:///sr.nellco.org/nyu_lewp/438. Accessed on: October 22, 2021.

DAVIS, Kevin E. What Counts as a Good Settlement? In: MAKINWA, Abiola; SØREIDE, Tina (org.). Negotiated Settlements in Bribery Cases. Cheltenham: Edward Elgar, 2020.

DAVIS, Kevin E. Between Impunity and Imperialism: The Regulation of Transnational Bribery. New York: Oxford University Press, 2019.

DAVIS, Kevin E. Does the Globalization of Anti-Corruption Law Help Developing Countries? In: FAUNDEZ, Julio; TAN, Celine (ed.). International Law, Economic Globalization and Development. Cheltenham: Edward Elgar, 2010. p. 9-52.

DAVIS, Kevin E.; JORGE, Guillermo; MACHADO, Maíra R. Transnational Anticorruption Law in Action: Cases from Argentina and Brazil. Law \& Social Inquiry, v. 40, n. 3, p. 664-699, 2015.

DELACIÓN premiada en Brasil; colaboración eficaz en el Perú: una comparación. IDL - Reporteros. 17.02.2018. Available at: https://www.idl-reporteros.pe/delacion-premiada-en-brasil-colaboracioneficaz-en-el-peru-una-comparacion/. Access on: April 20, 2021.

EL ACUERDO. IDL - Reporteros. 2018. Available at: https://www.docdroid.net/n8hjoRa/acuerdovela-jdp-con-odebrecht-pdf. Accessed on: April 20, 2021.

ESTADOS Unidos critica debilidad en investigación Odebrecht. NOTICIAS SIN. 2020. Avaliable at: https: / / noticiassin.com/pais/ estados-unidos-critica-corrupcion-e-impunidad-en-rd-959774. Accessed on: July 14, 2021.

GASPAR, Malu. A organização: a Odebrecht e o esquema de corrupção que chocou o mundo. São Paulo, Companhia das Letras, 2020. 
GENTILE, Rogério; LANDIM, Raquel. Odebrecht deixa de pagar multa na República Dominicana. Folha de S.Paulo. 2019. Available at: https: / /www1.folha.uol.com.br/mercado/2019/09/odebrechtdeixa-de-pagar-multa-por-corrupcao-na-republica-dominicana.shtml. Accessed on: April 20, 2021.

GONZÁLEZ OCANTOS, Ezequiel; BARAYBAR, K. V. Lava Jato Beyond Borders: The Uneven Performance of Anti-Corruption Judicial Efforts in Latin America. Taiwan Journal of Democracy, v. 15, n. 1, 2019.

GORRITI, Gustavo. Fiscalía brasileña aprobó que Barata no declare. IDL - Reporteros. 2017. Available at: https://www.idl-reporteros.pe/fiscalia-brasilena-aprobo-que-barata-no-declare/. Accessed on: April 20, 2021.

GORRITI, Gustavo. Interrogatorio en Curitiba: lo que dijo Odebrecht sobre el Perú. IDL - Reporteros. 2017. Available at: https: / /www.idl-reporteros.pe/interrogatorioen-curitiba/. Accessed on: April 20, 2021.

GRAÑA y Montero inició proceso de colaboración eficaz con la fiscalía. EL COMERCIO. 2019. Available at: https: / / elcomercio.pe/politica/grana-montero-inicio-proceso-colaboracion-eficaz-fiscalia-noticia640651-noticia/. Accessed on: April 20, 2021.

EINBINDERT, Fred. Corruption Abroad: From Conflict to Co-Operation: A Comparison of French and American Law and Practice. International Comparative, Policy \& Ethics Law Review, v. 3, p. 667-800, 2020.

IVORY, Radha.; SØREIDE, Tina. The International Endorsement of Corporate Settlements in Foreign Bribery Cases. International and Comparative Law Quarterly, v. 69, n. 4, p. 945-978, out. 2020.

HACKED chats expose questionable methods used by Swiss and Brazilian prosecutors. SWI SWIswissinfo.ch. 2021. Available at: https://www.swissinfo.ch/eng/hacked-chats-expose-questionablecooperation-between-swiss-and-brazilian-prosecutors/46371446. Accessed on: April 20, 2021.

HOCK, Branislav. Transnational Bribery: When Is Extraterritoriality Appropriate? Charleston Law Review, v. 11, 2017.

HERDY, Thiago. Chaves para abrir segredos da Odebrecht estão perdidas. Investigadores podem jamais ter acesso a um dos sistemas de propinas da empreiteira. O Globo. 2018. Available at: https: / /oglobo. globo.com/brasil/chaves-para-abrir-segredos-da-odebrecht-estao-perdidas-22339404. Accessed on: April 20, 2021. 
HIRATA, Taís. Odebrecht muda de nome e passa a se chamar Novonor. Valor Econômico. 18.12.2020. Available at: https: / /valor.globo.com/empresas/noticia/2020/12/18/odebrecht-muda-de-nome-epassa-a-se-chamar-novonor.ghtml. Accessed on: July 16, 2021.

HOLTMEIER, Jay. Cross-border Corruption Enforcement: A Case for Measured Coordination among Multiple Enforcement Authorities. Fordham Law Review, v. 84, p. 493, 2015.

INTERNATIONAL CHAMBER OF COMMERCE IN BELGIUM. Media release. Billed as an event to "Meet the Enforcers," an array of United States (U.S.) agents and prosecutors active in tackling corruption and fraud in Brazil descended onto São Paulo last week to discuss cooperating in effective anti-corruption strategies with ICC Brazil and local business executives. 2018. Available at: https://www.iccwbo. be/private-sector-and-fbi-discuss-ethics-in-brazilian-business/. Accessed on: April 20, 2021.

TRANSPARENNCIA INTERNACIONAL BRASIL. Lava Jato pelo Mundo, Jota, 2019. Available at: https://www.jota.info/tudo-sobre/lava-jato-pelo-mundo. Access on: 20.04.2021.

JUSTIÇA de São Paulo aceita pedido de recuperação judicial da Odebrecht. Conjur. 2019. Available at: https: / / www.conjur.com.br/2019-jun-19/justica-aceita-pedido-recuperacao-judicial-odebrecht. Accessed on: April 20, 2021.

LAGUNES, Paul F.; SVEJNAR, Jan (ed.). Corruption and the Lava Jato Scandal in Latin America. Routledge, 2020.

LAS PRUEBAS que entregará Odebrecht. IDL-Reporteros. 2019. Available at: https://www.idlreporteros.pe/las-pruebas-que-entregara-odebrecht/. Accessed on: April 20, 2021.

LOW, Lucinda A.; PRELOGAR, Brittany. Incentives for self-reporting and cooperation. In: MAKINWA, Abiola; SØREIDE, Tina (org.). Negotiated Settlements in Bribery Cases. Edward Elgar, 2020.

MACHADO, Maíra R.; FERREIRA, Luísa. Estudos sobre o Caso TRT. São Paulo: Acadêmica Livre, 2014.

MACHADO, Maíra R.; PASCHOAL, Bruno. Monitorar, investigar, responsabilizar e sancionar: a multiplicidade institucional em casos de corrupção. Novos estudos CEBRAP, v. 35, n. 1, p. 11-36, 2016.

MAKINWA, Abiola; SØREIDE, Tina. Structured Criminal Settlements: Towards Global Standards in Structured Criminal Settlements for Corruption Offences. The International Bar Association (IBA), AntiCorruption Committee, Structured Criminal Settlements Sub-Committee, 2018.

MELLA, Romina. Zona de naufragio. IDL - Reporteros. 2018. Available at: https://www.idl-reporteros. pe/zona-de-naufragio/. Accessed on: April 20, 2021. 
MINISTÉRIO DA JUSTIÇA, Cooperação jurídica internacional: balanço revela resultados positivos e avanços na área. October 3, 2018. Available at: https://www.justica.gov.br/news/collective-nitf-content1538601301.22. Accessed on: June 20, 2021.

MINISTÉRIO PÚBLICO FEDERAL, Caso Lava Jato: efeitos no exterior. 2021. Available at: http: / / www.mpf. mp.br/grandes-casos/lava-jato/efeitos-no-exterior. Accessed on: June 20, 2021.

MINISTRO Fachin determina que juiz analise pedido de ex-presidente Lula que aponta nulidade de provas da Odebrecht. Supremo Tribunal Federal. 2021. Available at: http://portal.stf.jus.br/noticias / verNoticiaDetalhe.asp?idConteudo=461148\&tip=UN. Accessed on: July 16, 2021.

MURPHY-JOHNSON, Dawn E. FBI's New Miami-Based Corruption Squad Highlights Enforcement Focus on Latin America. FCPAméricas Blog. 2019. Available at: http://fcpamericas.com/english/anti-moneylaundering/fbis-miami-based-corruption-squad-highlights-enforcement-focus-latin-america/. Accessed on: April 20, 2021.

OBSTRUCCIÓN EFICAZ. El Comercio. 2019. Available at: https://elcomercio.pe/opinion/editorial/ odebrecht-acuerdo-gasoducto-humala-ollanta-fuerza-popular-editorial-obstruccion-eficaz-noticia-ecpm650465-noticia/?ref=ecr. Accessed on: April 20, 2021.

ODEBRECHT ha pagado al Estado Peruano más de S/700 mlls. en reparaciones civiles e impuestos. El Comercio. 2019. Available at: https://elcomercio.pe/politica/odebrecht-ha-pagado-al-estadoperuano-mas-de-s700-mlls-en-reparaciones-civiles-e-impuestos-noticia/?ref=ecr. Accessed on: April $20,2021$.

ODEBRECHT. Court-Supervised Reorganization of Odebrecht S.A. Communication. 2019. Available at: https: / /www.odebrecht.com/en/communication/court-supervised-reorganization-odebrechtsa. Accessed on: April 20, 2021.

ODEBRECHT. Communication. Odebrecht signs agreement with authorities in Brazil, United States and Switzerland. 2016. Available at: https: / / www.odebrecht.com/en/communication/releases/odebrechtsigns-agreement-authorities-brazil-united-states-and-switzerland. Accessed on: April 20, 2021.

ODEBRECHT. Timeline - Learn about what Odebrecht is doing to achieve sustainability in the business environment. 2021. Available at: https:/ / www.nossocompromisso.com/en/timeline/. Accessed on: April $20,2021$.

ODED, Sharon. The DOJs Anti-Piling-On Policy: Time to Reflect? In: MAKINWA, Abiola; SØREIDE, Tina (ed.). Negotiated Settlements in Bribery Cases: A Principled Approach. Cheltenham: Edward Elgar, 2020. 
ODUOR, Jacinta Anyango et al. Left Out of the Bargain: Settlements in Foreign Bribery Cases and Implications for Asset Recovery. Washington, DC: The World Bank, 2014.

OECD. Resolving Foreign Bribery Cases with Non-Trial Resolutions: Settlements and Non-Trial Agreements by Parties to the Anti-Bribery Convention. 2019. Available at: www.oecd.org/corruption/Resolving-ForeignBribery-Cases-with-Non-Trial-Resolutions.htm. Accessed on: April 20, 2021.

OECD. Working Group on Bribery. Peru: Phase 1 Report Implementing the OECD Anti-Bribery Convention. 2019a. Available at: http://www.oecd.org/corruption/anti-bribery/OECD-Phase-1Report-Peru-ENG.pdf. Accessed on: April 20, 2021.

OECD Conference Center. Agenda on the Third Meeting of the Global Network of Law Enforcement Practitioners Against Transnational Bribery. 2019b. Available at: https: / /www.oecd.org/corruption/anti-bribery/GlobalLaw-Enforcement-Network-Meeting-Agenda-2019.pdf. Accessed on: July 20, 2021.

OECD. The Detection of Foreign Bribery. 2017. Available at www.oecd.org/corruption/the-detection-offoreign-bribery.htm Accessed on: April 20, 2021.

OECD. Overcoming International Co-Operation Challenges in Corruption Cases. 2016. Available at: https: / / www.oecd.org/corruption/international-co-operation-in-combating-foreign-bribery.htm. Accessed on: July 20, 2021.

OECD. Typology on Mutual Legal Assistance in Foreign Bribery Cases. 2012. Available at: https://www. oecd.org/daf/anti-bribery/TypologyMLA2012.pdf. Accessed on: April 20, 2021.

PERU. Ministerio Público; Procuraduría Pública Ad Hoc; Odebrecht S.A. Acta de Acuerdo Preparatorio de Colaboración y Beneficios. 2018. Available at: https://www.docdroid.net/n8hjoRa/acuerdo-vela-jdp-conodebrecht-pdf. Accessed on: April 20, 2021.

PERU; BRAZIL. Pedido de cooperação internacional AJ n. 68-17. Procedimento de Cooperação Internacional $\mathrm{n}^{\mathrm{o}}$ 1.00.000.006776/2017-34 (PGR). 2017.

PETERS, B. Guy. Pursuing Horizontal Management. Lawrence: University Press of Kansas, 2015.

PIETH, Mark; LOW, Lucinda A.; CULLEN, Peter J. (ed.). The OECD Convention on Bribery: A Commentary. Cambridge: Cambridge University Press, 2007.

PIETH, Mark. Negotiating Settlements in a Broader Law Enforcement Context. In: MAKINWA, Abiola; SØREIDE, Tina (org.). Negotiated Settlements in Bribery Cases. Cheltenham: Edward Elgar, 2020. 
PIMENTA, Raquel de Mattos. Construção dos acordos de leniência da lei anticorrupção. São Paulo: Blucher, 2020.

PIMENTA, Raquel de Mattos; GREENE, Catherine. Comparing Peru and Mexico in the Lava Jato Scandal. In: LAGUNES, Paul; SVEJNAR, Jan (ed.). Corruption and the Lava Jato Scandal in Latin America. Routledge Corruption and Anti-Corruption Studies. New York: Routledge, p. 142-64, 2020.

PRADO, Mariana Mota; CORNELIUS, Eduardo. Multiplicidade institucional e a luta contra a corrupção: uma agenda de pesquisa para a rede de accountability brasileira. Revista Direito GV, v. 16, n. 3, 2020.

PRADO, Mariana Mota; CARSON, L. Brazilian Anti-Corruption Legislation and Its Enforcement: Potential Lessons for Institutional Design. Manchester: The University of Manchester, 2014. Available at: https://ideas.repec.org/p/bwp/bwppap/iriba_wp09.html. Accessed on: April 20, 2021.

PROCURADURÍA recibe segundo pago de US\$30 millones de la empresa Odebrecht. El Día. 2018. Available at: https: / / eldia.com.do/procuraduria-recibe-segundo-pago-de-us30-millones-de-la-empresaodebrecht/. Accessed on: April 20, 2021.

RAUSTIALA, Kal; VICTOR, David G. The Regime Complex for Plant Genetic Resources. International Organization, v. 58, n. 2, p. 277-309, 2004.

REPÚBLICA DOMINICANA. Ministerio Público; Odebrecht S. A. Tercer Juzgado de la Instrucción del Distrito Nacional. Núm. Resolución: 059-2017-SRES-00098/RP, Processo nº : 059-2017-EPEN-00249. 2017. Available at: https: / /pgr.gob.do/wp-content/uploads / 2017/04/Resolucion-059-2017-SRES00098RP.pdf. Accessed on: April 20, 2021.

RODAS, Sérgio. Procuradores não quiseram que documentos da Suíça passassem pelo governo. Consultor Jurídico. 29.03.2021. Available at: https: / /www. conjur.com.br/2021-mar-29/procuradores-naoquiseram-documentos-suica-passassem-mj. Accessed on: April 20, 2021.

RODRÍGUEZ-OLIVARI, Denisse. Fighting Corruption in a Hostile Environment: Peru's Lava Jato Special Prosecution Team. In: LAGUNES, Paul; SVEJNAR, Jan (ed.). Corruption and the Lava Jato Scandal in Latin America. Routledge Corruption and Anti-Corruption Studies. New York: Routledge, 2020.

ROSE, Cecily. International Anti-Corruption Norms: Their Creation and Influence on Domestic Legal Systems. Oxford: Oxford University Press, 2015.

SANCHEZ-BADIN, Michelle Ratton; SANCHEZ-BADIN, Arthur. Anticorruption in Brazil: From Transnational Legal Order to Disorder. AJIL Unbound, v. 113, p. 326-330, 2019. 
SEAWRIGHT, Jason; GERRING, John. Case Selection Techniques in Case Study Research: A Menu of Qualitative and Quantitative Options. Political Research Quarterly, v. 61, n. 2, 2008.

SECRETÁRIA que revelou departamento de propina da Odebrecht depõe. G1. 03.02.2017. Available at: http://g1.globo.com/jornal-nacional/noticia/2017/02/secretaria-que-revelou-departamentode-propina-da-odebrecht-depoe.html. Accessed on: April 20, 2021.

SE FILTRÓ el Acta del Acuerdo del Equipo Especial con Odebrecht. La República. 2019. Available at: https://larepublica.pe/politica/1398570-filtro-acta-acuerdo-equipo-especial-odebrecht/?ref=lre. Accessed on: April 20, 2021.

SWITZERLAND. Office of the Attorney General. Petrobras - Odebrecht Affair: The Office of the Attorney General of Switzerland Convicts Brazilian Companies and Demands Payment of over CHF 200 Million. 2016. Available at: https:/ / www.bundesanwaltschaft.ch/mpc/en/home/medien/archivmedienmitteilungen/news-seite.msg-id-65077.html. Accessed on: April 20, 2021.

THE AS/COA ANTI-CORRUPTION WORKING GROUP (AWG). The 2020 Capacity to Combat Corruption (CCC) Index. 2020. Available at: https://www.as-coa.org/sites/default/files/archive/2020_ CCC_Report.pdf. Accessed on: April 20, 2021.

TRANSPARENCY INTERNATIONAL, Exporting Corruption Progress Report. 2020. Available at: https: / / images.transparencycdn.org/images/2020_Report_ExportingCorruptionFull_English.pdf. Accessed on: April 20, 2021.

UNITED STATES OF AMERICA. Criminal Division of the U.S. Department of Justice. Enforcement Division of the U.S. Securities and Exchange Commission. A Resource Guide to the U.S. Foreign Corrupt Practices Act. $2^{\text {nd }}$ ed. 2020. Available at: https://www.justice.gov/criminal-fraud/file/1292051/ download. Accessed on: April 20, 2021.

UNITED STATES OF AMERICA. Department of Justice, United States Attorney's Office for the Eastern District of New York. Odebrecht S.A. Plea Agreement. 2016. Available at: https: //www. justice.gov/opa/press-release/file/919916/download. Accessed on: April 20, 2021.

UNITED STATES OF AMERICA. United States of America v. Odebrecht S.A. Criminal Docket Number: 16 643 (RJD). Dearie J. 2017. Available at: https://www.courtlistener.com/docket/4556656/17/ united-states-v-odebrecht/. Accessed on: April 20, 2021.

UNITED STATES OF AMERICA. U.S. Department of Justice. Airbus Agrees to Pay over \$3.9 Billion in Global Penalties to Resolve Foreign Bribery and ITAR Case. News Release. 2020. Available at: https://www.justice. 
gov/opa/pr/airbus-agrees-pay-over-39-billion-global-penalties-resolve-foreign-bribery-and-itar-case. Accessed on: January 31, 2021.

UNITED STATES OF AMERICA. U.S. Department of Justice. Former Siemens Executive Pleads Guilty to Role in \$100 Million Foreign Bribery Scheme. News Release. 2018. Available at: https: / www.justice.gov/opa/pr/ former-siemens-executive-pleads-guilty-role-100-million-foreign-bribery-scheme. Accessed on: March 15, 2021.

UNITED STATES OF AMERICA. U.S. Department of Justice. Odebrecht and Braskem Plead Guilty and Agree to Pay at Least \$3.5 Billion in Global Penalties to Resolve Largest Foreign Bribery Case in History. News Release. 2016. Available at: https://www.justice.gov/opa/pr/odebrecht-and-braskem-plead-guilty-and-agreepay-least-35-billion-global-penalties-resolve. Accessed on: April 20, 2021.

UNODC, Legislative Guide for the Implementation of the United Nations Convention against Corruption. 2. ed. New York: United Nations, 2012.

VARADOS EN BAHIA. IDL - Reporteros. 04.07.2018. Available at: https://www.idl-reporteros.pe/ varados-en-bahia/. Accessed on: April 20, 2021.

VASCONCELLOS, Marcos de. Pedalada probatória: Ministério Público driblou a lei para trazer documentos da Suíça na Lava Jato. Consultor Jurídico, January 5, 2015. Available at: https://www. conjur.com.br/2015-nov-05/documentos-trazidos-suica-mpf-colocam-lava-jato-risco. Accessed on: April 20, 2021.

VENTURINI, Otavio. Teorias do direito administrativo global e standards: desafios à estatalidade do Direito. São Paulo: Almedina, 2020.

\section{HOW TO QUOTE THIS ARTICLE:}

PIMENTA, Raquel de Mattos; VENTURINI, Otavio. International Cooperation and Negotiated Settlements for Transnational Bribery: A Study of the Odebrecht Case. Revista Direito GV, São Paulo, v. 17, n. 2, maio/ago. 2021, e2131. https://doi.org/ 10.1590/2317-6172202131
Raquel de Mattos Pimenta Professor at São Paulo LaW School (FGV DiREITO SP). raquel.pimentalafgv.br

Otavio Venturini Doctoral student at São Paulo Law School (FGV DiReito SPI. MASTER DEgREE AT FGV DIREITO SP. otavioventuriniahotmail.com 